\title{
Quantum Character
}

\section{Commentary on Lerner and Schmid Callina}

\author{
Marvin W. Berkowitz
}

University of Missouri-St. Louis, St. Louis, Mo., USA

\author{
Key Words \\ Character $\cdot$ Development $\cdot$ Systems
}

Lerner and Schmid Callina [this issue], in their article "The Study of Character Development: Towards Tests of a Relational Developmental Systems Model," propose to advance research on specifically the development of character by proposing a theoretical framework of particular value, namely a relational developmental systems (RDS) model [Overton \& Müller, 2013]. The justification lies in the understanding that character is developmental, multidimensional, and dynamic. Hence the traditional taxonomic approaches that simply list the sub-categories of character are insufficient to fully capture the ontogenetic complexity of character. I recall chiding Marty Seligman when the Character Strengths and Virtues handbook [Peterson \& Seligman, 2004], of which I was a contributing author, was first published that there was a dearth of developmental theory in this model. It impressively described and mapped the terrain of character, but not how it developed. Lerner and Schmid Callina have rightfully diagnosed this same problem still existing a decade later. And this attempt to begin the discussion of how to think about the overall development of character is therefore welcome and important.

Nevertheless, there tends to be residual tension in this particular way of characterizing character and its development. One of the challenges is that the definition of character in this paper is often off target or unhelpful and, in part, due to an RDS focus. An overemphasis on process at the expense of the nature of the developing person contributes to this, and to other challenges discussed below. At one point the authors define character as a "set of mutually beneficial relations." But character is not relations; rather, it is an aspect of the person that is influenced by, is transacted

\begin{tabular}{ll}
\hline KARGER & $\odot 2015$ S. Karger AG, Basel \\
$\begin{array}{l}\text { E-Mail karger@karger.com } \\
\text { www.karger.com/hde }\end{array}$ &
\end{tabular}

Dr. Marvin W. Berkowitz

Center for Character and Citizenship, 402 Marillac Hall College of Education, University of Missouri-St. Louis One University Blvd., St. Louis, MO 63121-4400 (USA) E-Mail berkowitz@umsl.edu 
in, and reciprocally impacts relations. To support their perspective, they quote Nucci's focus on "human welfare, justice and rights, which are a function of inherent features of interpersonal relations" and one of my chapters that argues that character "invariably involves interpersonal relations that reflect a public system of universal concerns about human welfare, justice, and rights that all rational people would want others to adhere to" [Berkowitz, 2012, p. 249]. In both cases, these are not definitions of character but rather definitions of morality, toward which character is ideally directed. Lerner and Schmid Callina appear to be defining character by its influences (i.e., relations) and one of its domains of application (i.e., morality) rather than by its psychological nature (e.g., cognition, personality, affect). Elsewhere, I have defined character as "the composite of those characteristics of the individual that directly motivate and enable him or her to act as a moral agent" [Berkowitz, 2012, p. 248]. This definition is in full alignment with Lerner and Schmid Callina's contention that character is developmental, multidimensional, and dynamic. Granted, it skews in the opposite direction of the process-description dichotomy - namely, it does not adequately highlight the role of relations and context on character. But that is because it is intended to define character, which I will contend resides in the person and not in the relations of which the person is part and which, as Lerner and Schmid Callina rightly point out, impacts the development and behavioral manifestations of character. It is important to note that this is my definition specifically of moral character. When one begins to add other aspects of character such as intellectual character [Baehr, 2011] and civic character [Althof \& Berkowitz, 2006], the definition becomes even more complex.

There has been a long-standing neglect of a scientific focus on character development, as noted by Lerner and Schmid Callina. In part, this is due to the common conflation of character, character development, and character education, broadly defined [Berkowitz, 2012], a mistake which Lerner and Schmid Callina seem to make. Even if we take RDS in an orthodox manner, focusing heavily on the dynamic fluid aspect of character, it is still useful for theorists, researchers, and practitioners to describe character in a static fashion - i.e., as a moment in time. We can still recognize that, while it may be dynamic, at any given moment in time it can be examined and described. That is indeed the general connotation of "having" character. Nonetheless, if Lerner and Schmid Callina are correct that character is fluid and dynamic - and I believe they are to a large degree (more on this below) -, we need to understand that character is always developing. That is, character changes and evolves, sometimes in normative ways and sometimes in nonnormative ways. The question is what is this "thing" that is changing and developing? Surely it is more than its influences. Character is more than a transitory tabula rasa upon which the world writes with erasable markers. As Piaget pointed out long ago, not only does the object resist the child, but the child resists and makes meaning of the object. Or to put it more simply, if we could have a child with little or no relations or context, that child would still have character, but if we had a buzzing rich world with no child in it, there would be no character. Recognizing the role of relations and dynamic interactions with the environment is critical to understanding character; prioritizing it over the nature of the child is distortive.

In fact, in the RDS model upon which Lerner and Schmid Callina depend so centrally, the first "moment" in the research process ("the identity of opposites") in essence is a recognition of the eternal interdependence of the developing organism and 
the fluid dynamic influences on that individual's development and functioning. Furthermore, it is the second moment ("the opposites of identity") wherein one focuses on the static nature of the organism in the current moment, even while recognizing that this is an artificial move because of the interdependent dynamic nature of the person-context developmental relationship.

As we consider the differences between character, character development and character education, we can see the different parts of this model more clearly. Understanding the influences in this dynamic, such as relationships with others and the context in which the person exists, on the developing organism is character development. This is the focus in the first and third moments. It is in the second moment, when we focus more narrowly on the state of the organism, however, that we turn to character. For those with applied interests in actually impacting the development of character, translating this descriptive (character) and developmental (character development) knowledge to impact the systems and relations of influence becomes particularly important. This is character education, whether it is in schools, families, or other systems that influence development. These distinctions are rarely held theoretically or rhetorically in any systematic manner.

At many points, Lerner and Schmid Callina have swung the pendulum back from a too static descriptive notion of character to a dynamic systems focus. This pendulum has swung in both directions before. When Hartshorne and May [1928, 1930], as noted by Lerner and Schmid Callina, argued that there is no such thing as stable character based on their findings that character was situationally determined, the long-standing notion of stable static character was weakened. It is much easier to think of character in a static stable way; the RDS model is conceptually complex and challenging. So it is not surprising that the pendulum swung back; however, this was also due to flaws in Hartshorne and May's data and reasoning. I would argue that this new "swing" goes too far in the dynamic direction, characterizing character as too fluid and dynamic. In one sense, it tends to negate, or at least minimize, the person. If one is always determined by process and context, the existential question arises as to whether one exists in any meaningful sense. What is the role of the person; is it merely (and ironically) some Lockean tabula rasa?

Another way to approach this is to shift the metaphor from a pendulum to quantum physics. The dynamic versus static tension reminds me of many other dichotomies that have proven less than fruitful, except as part of the dialectic of scientific understanding. Most relevant here is the nature versus nurture debate in developmental theory. At first the question was, "Which one is it, nature or nurture, that influences development?" This shifted, when the first question was unanswerable, to a quantitative question of how much each impacted development. This too was reduced to absurdity in many cases and ultimately the question morphed into one of how nature and nurture interact to produce development. (An interesting side note is that I first learned this as an undergraduate in Bill Overton's developmental psychology class at the University of Buffalo in 1971.) In physics, a similar question was whether certain phenomena had properties of waves or particles. Ultimately, this either/or shifted to a rather conceptually challenging notion that some phenomena may be both particles and waves. This notion maps nicely onto the first and third moments in Overton and Müller's [2013] RDS model if we associate the particles with fixed features of character and the waves as the dynamic and fluid nature of development. Granted, it is far from a perfect metaphor, but it may be helpful here. 
Certainly, in many ways Lerner and Schmid Callina "get it" - for example when they highlight the role of individual agency in character development. Nevertheless, the skew is toward the dynamic process and at many points the idea of static character traits is rejected, as in the critique of McCrae, Costa, Hrebickova, Ostendord, Angleitner, Avia, \& Smith [2000]: "Any representation of the variables indexing character needs to depict relational constructs, and not within-the-person entities and certainly not traits" (as noted by Lerner and Schmid Callina). The broader personality development literature has long contended with another dualism: variability versus stability of personality constructs, particularly in adult development. Again, as is often the case with dualisms, it is overly simplistic and hence distortive. Personality is at once both static and variable, and what one sees is largely due to the methods one uses to study it, despite Lerner and Schmid Callina's contention that "the purported life-span stability of traits, as well as the purported immunity to contextual influences, are empirically counterfactual." The RDS focus on character as "relatively plastic" raises the same issue. Mercury and putty are "relatively plastic," but they exist and have very stable features, some of which account for their plasticity. In fact, to support this line of argument, Lerner and Schmid Callina cite my work with Sokol and Hammond [Sokol, Hammond, \& Berkowitz, 2010] in which we reject the notion that character is a "fixed feature of a person" (p. 584), adding highlights to the word "fixed." But this is really a theoretical straw man, as nothing in human nature is absolutely fixed or immune to contextual influences.

Nearly four decades ago, Klaus Riegel [1976] argued for a dialectical notion of human development, in part in reaction to the seemingly static developmental perspective of cognitive-structural theory. In some ways, RDS and Lerner and Schmid Callina invoke this rejection of static descriptions of stages of development. As one who cut his scholarly teeth in Kohlbergian moral psychology, it was disconcerting for me to see Kohlberg reduced to a "fixed person" theorist here. In fact, when Lerner and Schmid Callina offer a counterpoint to Kohlberg, arguing that

Character is not a trait-like phenomenon but, instead, is a multidimensional, relatively plastic feature of adaptive developmental regulations, of mutually beneficial individual $\leftarrow \rightarrow$ context relations. These relations may involve the manifestation of behavior that, while showing variation across time and place, may, nevertheless, at a more abstract (e.g., latent variable) level, reflect coherence in functioning to provide mutual benefit to individual and context within the integrated, relational developmental system

they are in fact supporting precisely the reason Kohlberg focused on reasoning structures over character traits. Reasoning structures are coherent even when generating variation in resulting conclusions and behavior. Coherence, which Lerner and Schmid Callina tend to prioritize, may not in fact describe character other than in some Aristotelian ideal state of maturity. Furthermore, coherence, from this perspective, may itself be a developmental phenomenon with greater coherence being a more mature state, in a fully Wernerian sense [Werner, 1948].

It may be more useful to think of character as a set of conceptually related psychological constructs and not as a single phenomenon. In various guises, I have tried to describe what I call a "moral anatomy" [Berkowitz, 1997, 2012], highlighting the multi-faceted nature of the moral person. There are diverse cognitive, personality, affective and motivational, and behavioral components. Each has its own unique developmental trajectory. As Kochanska [1993] and her colleagues have amply demon- 
strated, for example, conscience is an early developmental product of the interplay of biologically based aspects of personality (temperament) and environmental experiences, most notably parenting. Moral reasoning [Kohlberg, 1984], on the other hand, is largely a cognitive and slower life-span product of the interaction of the person's current reasoning capacities, other necessary cognitive capacities [Walker, 1980], and the nature of the socio-moral world that the individual confronts. Alternatively one could look at the developmental trajectory of empathy [Hoffman, 2000] or many other aspects of character. At the core of this is the self-system [Bergman, 2004; Berkowitz, 2012], both an integrating aspect of character and another unique developmental phenomenon. In fact, this may be what Lerner and Schmid Callina are touching upon when they prioritize the role of agency in character development.

It is helpful that Lerner and Schmid Callina spend an appreciable portion of the paper on application. It is a bit anomalous, however, that they focus so heavily on social change. Certainly social change, or rather social progress (positive change), is a good that ideally will come from individual character. However, developmental psychology is about human development and not about sociological development. Again, this trajectory of the developmental course needs to be understood as varying across character phenomena, as noted above. Person perception, as is true for many social cognitive phenomena, develops somewhat predictably in childhood and adolescence as the cognitive substrate upon which one's understanding of others depends develops through a predictable series of structures of meaning making [Livesley \& Bromley, 1973]. Regression is very unlikely. These stages are part of the cognitive make-up of the person, although they are impacted by experience with the social world. One's template of relationships, resulting from one's attachment history, alternatively tends mostly to form early in one's development and stay reasonably stable throughout the life course, with profound psychological implications [Sroufe \& Waters, 1977].

In other words, character is indeed multidimensional with quite variable subcomponents, and the dynamic systems perspective on its development needs to recognize that. This continues to be a problem as Lerner and Schmid Callina turn to ways to test their model. It is precisely those quite diverse examples noted above (attachment, person perception, conscience, empathy, moral reasoning) that stretch this model. It is worth noting that, while Lerner and Schmid Callina rightly point to the difficulty in navigating across the taxonomies of character, Liston [2014] has recently both generated a taxonomy that integrates the major models of character and validated an initial measure supporting a complex 11-factor integrative scheme.

Lastly, while more theoretically driven evaluations of character education are needed, and evaluations that explore some of the more complex empirical questions wisely raised by Lerner and Schmid Callina are relatively rare, there are many good examples of such research already. Wentzel's [2002] study of middle school teachers, their use of strategies analogous to effective parenting practices, and its impact on character, behavior and academic achievement is one example. Watson's [2003] twoyear action research study of developmental discipline in an elementary classroom, relying on attachment theory to intervene with the prosocial development of students, is another. Certainly, as Lerner and Schmid Callina note, more longitudinal studies are desperately needed. Lerner and Schmid Callina do a great service by bringing our attention to the need for theory-driven character research, and the fact that useful theories must recognize the multidimensional and dynamic interactional na- 
ture of character. I would add that we dare not throw out the epistemic baby with the bathwater or, better yet, with the Hessian stream from which Siddhartha garnered his version of RDS inspiration. Rather, as Lerner and Schmid Callina remind us, we need to make a quantum leap and embrace both the particle (components of character) and the wave (relational dynamics) in character development.

\section{References}

Althof, W., \& Berkowitz, M.W. (2006). Moral education and character education: Their relationship and their roles in citizenship education. Journal of Moral Education, 35, 495-518.

Baehr, J. (2011). The inquiring mind: On intellectual virtues \& virtue epistemology. New York, NY: Oxford University Press.

Bergman, R. (2004). Identity as motivation: Toward a theory of the moral self. In D.K. Lapsley \& D. Narvaez (Eds.), Moral development, self, and identity (pp. 21-46). Mahwah, NJ: Erlbaum.

Berkowitz, M.W. (1997). The complete moral person: Anatomy and formation. In J.M. Dubois (Ed.), Moral issues in psychology: Personalist contributions to selected problems (pp. 11-41). Lanham, MD: University Press of America.

Berkowitz, M.W. (2012). Moral and character education. In K.R. Harris, S. Graham, \& T. Urdan (Eds.), APA educational psychology handbook. Vol. 2: Individual differences, cultural variations, and contextual factors in educational psychology (pp. 247-264). Washington, DC: American Psychological Association.

Hartshorne, H., \& May, M.A. (1928). Studies in the nature of character. Vol. I: Studies in deceit. New York, NY: Macmillan.

Hartshorne, H., \& May, M.A. (1930). A summary of the work of the character education inquiry. Religious Education, 25, 609-611.

Hoffman, M.L. (2000). Empathy and moral development: Implications for caring and justice. New York, NY: Cambridge University Press.

Kochanska, G. (1993). Toward a synthesis of parental socialization and child temperament in early development of conscience. Child Development, 64, 325-347.

Kohlberg, L. (1984). The psychology of moral development. San Francisco, CA: Harper \& Row.

Liston, M. (2014). Conceptualizing and validating the Character Virtues Index (CVI) (order No. 3633828, University of Missouri, Saint Louis). ProQuest Dissertations and Theses, 334. Retrieved from http:// search.proquest.com/docview/1611144972?accountid=35915 (1611144972).

Livesley, W.J., \& Bromley, D.B. (1973). Person perception in childhood and adolescence. New York, NY: J. Wiley \& Sons.

McCrae, R.R., Costa, P.T., Hrebickova, M., Ostendord, F., Angleitner, A., Avia, M.D., \& Smith, P.B. (2000). Nature over nurture: Temperament, personality, and life span development. Journal of Personality and Social Psychology, 78, 173-186.

Overton, W.F., \& Müller, U. (2013). Metatheories, theories, and concepts in the study of development. In R.M. Lerner, M.A. Easterbrooks, \& J. Mistry (Eds.), Handbook of psychology. Vol. 6: Developmental psychology (2nd ed., pp. 19-58). Editor-in-Chief: Irving B. Weiner. Hoboken, NJ: Wiley.

Peterson, C., \& Seligman, M.E.P. (2004). Character strengths and virtues: A handbook and classification. Washington, DC: APA Press and Oxford University Press.

Riegel, K.F. (1976). The dialectics of human development. American Psychologist, 31, 689-700.

Sokol, B.W., Hammond, S.I., \& Berkowitz, M.W. (2010). The developmental contours of character. In T. Lovat, R. Toomey, \& N. Clement (Eds.), International research handbook on values education and student wellbeing (pp. 579-603). Dordrecht, Netherlands: Springer.

Sroufe, L.A., \& Waters, E. (1977). Attachment as an organizational construct. Child Development, 48, 1184-1199.

Walker, L.J. (1980). Cognitive and perspective-taking prerequisites for moral development. Child Development, 51, 131-139.

Watson, M. (2003). Learning to trust. San Francisco, CA: Jossey-Bass.

Wentzel, K.R. (2002). Are effective teachers like good parents? Teaching styles and student adjustment in early adolescence. Child Development, 73, 287-301.

Werner, H. (1948). Comparative psychology of mental development. Oxford, England: Follett. 